\title{
A Poetics of Laughter: Characterizing the African Comic Novel
}

\section{Maik Nwosu}

\section{(2) OpenEdition \\ 1 Journals}

Electronic version

URL: https://journals.openedition.org/ces/8399

DOI: $10.4000 /$ ces.8399

ISSN: 2534-6695

\section{Publisher}

SEPC (Société d'études des pays du Commonwealth)

\section{Printed version}

Date of publication: 1 April 2010

Number of pages: $35-46$

ISSN: 2270-0633

\section{Electronic reference}

Maik Nwosu, "A Poetics of Laughter: Characterizing the African Comic Novel", Commonwealth Essays and Studies [Online], 32.2 | 2010, Online since 17 December 2021, connection on 31 January 2022 URL: http://journals.openedition.org/ces/8399; DOI: https://doi.org/10.4000/ces.8399

\section{(c) (i) $\odot$}

Commonwealth Essays and Studies is licensed under a Licence Creative Commons Attribution - Pas d'Utilisation Commerciale - Pas de Modification 4.0 International. 


\section{A Poetics of Laughter: Characterizing the African Comic Novel}

The discussion of the African novel often focuses on the tragic or 'serious' novel, thus understating the existence of a comic novel tradition. Even though both the African comic novel and the African tragic novel are often shaped by the same sociopolitical experience, each genre is distinct in terms of technique. A characterization of the African comic novel, with Nkem Nwankwo's Danda and Mongo Beti's The Poor Christ of Bomba as primary examples, illustrates the nature of the comic or the poetics of laughter in the African novel - a poetics that ranges in this instance from the comic simplicitas of Danda to the comic magnitude in The Poor Christ of Bomba.

7 he discussion of the African novel often focuses on the tragic or 'serious' novel, thus emphasizing the textual orientation of this type of novel as shaped by contextual factors. The tradition of the comic novel in Africa is often understated. For instance, Chidi Amuta, who claims that "[a] common denominator of African literary scholarship [...] is a disturbing theoretical anaemia" (5), does not make the sort of generic distinction that distinguishes the comic from the tragic in The Theory of African Literature. Many of the well known and often-discussed modern African novels - such as Chinua Achebe's Things Fall Apart, Ngugi wa Thiong'o's Petals of Blood, Ahmadou Kourouma's The Suns of Independence, Naguib Mahfouz's Children of the Alley, Ben Okri's The Famished Road - are tragic or semi-tragic novelizations of the traditional or the contemporary African experience. Even though both the African comic novel and the African tragic novel are often shaped by the same sociopolitical experience, each genre is distinct in terms of technique. A characterization of the African comic novel, with Nkem Nwankwo's Danda and Mongo Beti's The Poor Christ of Bomba as primary examples, illustrates the nature of the comic or the poetics of laughter in the African novel - a poetics that ranges in this instance from the comic simplicitas of Danda to the comic magnitude in The Poor Christ of Bomba.

Nkem Nwankwo's novel, Danda, exemplifies comic density. Published in 1964, Danda is set in Igboland, as is Achebe's Things Fall Apart (1958), and the two novels more or less traverse the same socio-historical territory. But Nwankwo's novel does not have the same sort of gravitas as Things Fall Apart. Where the comic tendency in Achebe's novel, as is only tentatively suggested through the character of Unoka, is overshadowed by the overall tone and tragic mood of the novel, Nwankwo's intent is clearly to laugh at the assumptions and pretensions of the era in which his novel is set. Consider, for example, the exchange between Unoka and Chielo, the priestess, about Unoka's poor harvest: 
"Every year," he [Unoka] said sadly, "before I put any crop in the earth, I sacrifice a cock to Ani, the owner of all land. It is the law of our fathers. I also kill a cock at the shrine of Ifejioku, the god of yams. I clear the bush and set fire to it when it is dry. I sow the yams when the first rain has fallen, and stake them when the young tendrils appear. I weed-"

"Hold your peace!" screamed the priestess, her voice terrible as it echoed through the dark void. "You have offended neither the gods nor your fathers. And when a man is at peace with his gods and his ancestors, his harvest will be good or bad according to the strength of his arm. You, Unoka, are known in all the clan for the weakness of your machete and your hoe. When your neighbors go out with their ax to cut down virgin forests, you sow your yams on exhausted farms that take no labor to clear. They cross seven rivers to make their farms; you stay at home and offer sacrifices to a reluctant soil. Go home and work like a man" (17-18).

The comic potential in this exchange, initiated by Unoka, is seriously parenthesized both by its location - at the Shrine of the Oracle of the Hills and the Caves - and by the priestess's "terrible" characterization of Unoka. When Unoka later dies and is thrown into the evil forest and his 'failure' haunts his son (Okonkwo) relentlessly, the comic potential of his presence in the novel is even more de-emphasized. Unoka becomes more parabolic than comic. In contrast, the comic intent in Danda is evident in the overall texture of the narrative - especially through characterization and systemic contrast - and in Nwankwo's fusion of the comic and the parabolic. In many respects, the texture of Nwankwo's novel exemplifies the characteristic quality of the African comic novel. Characterization is particularly important.

Characterization is the main technique for plot realization or progression in the novel, as has been noted by critics as different as E.M. Forster and Mikhail Bakhtin. While Forster emphasizes the importance of "homo fictus" in the dramatization of the story (Aspects of the Novel 43-64), Bakhtin maps "social heteroglossia" and "character zones" - "the field of action for a character's voice, encroaching in one way or another upon the author's voice" (316). For Bakhtin, an aspect of carnivalization or the incorporation of "a multiplicity of 'language' and verbal-ideological belief systems" into the comic novel (311) exemplifies heteroglossia. However perceived or delineated, characterization is essential in the novel - whether tragic or comic. But characterization - the comic "I" or personality profile specifically - tends to be of greater importance in the comic novel. While the comic novel is often a novel of character, the tragic novel tends to be a novel of plot. This statement of tendency is important because all novels are, even if in various ways, novels of plot and character. According to Aristotle, however, character is of secondary importance in tragedy whereas plot is the "first principle." In tragedy, he notes, the plot needs to be "of a certain magnitude" in terms of length or complexity and seriousness or significance.

Following Aristotle, we can argue that while character, without which there would be no plot progression either in tragedy or comedy, is of course important, 
it is the magnitude or significance of plot that defines tragedy. Although he argues that tragedy may even exist without character (which "determines men's qualities") but not without action, Aristotle somewhat links character to plot in his discourse on hamartia or the tragic flaw. The magnitude of plot is linked to the weakness or seriousness of character. It is the gravity of Okonkwo's drive that makes him such a potentially tragic figure in Things Fall Apart, but Okonkwo's temperament is not the locus of tragedy in the novel. The site of tragedy is the catalytic convergence of different movements of history and the consequent rescripting of Okonkwo's possibilities. The site of tragedy often tends to be a point of convergence and crisis. In the comic novel, magnitude is usually deconstructed. Danda's characteristic question - "Why are we so solemn?" - is a pointer to the absence of seriousness in his perception of the world: a malleable world of always-becoming rather than of settled codes. Unlike in Things Fall Apart, the locus of comedy in Danda is largely Danda himself - almost in the tradition of the stand-up comedian. Once Danda appears, the comical manifests itself through what he looks like, what he says, and what he does (or does not do). This relocation of sites can be explained by the fact that while the comic can be momentary, the tragic is usually cumulative. So, there is such a thing as a comic (but not usually a tragic) relief.

It is also possible not to simply follow Aristotle but to qualify or problematize the two terms - character and magnitude - that Aristotle uses. Characterization in the context of comedy refers to a comic self - as distinct from a tragic self. The subject in either case is defined by character propensity (a predisposition to the comic, as in Danda's case) or character perception (an attribution of the comic to a character, as in the case of Father Drumont in The Poor Christ of Bomba). In this wise, it is not characterization per se that is of primary importance in comedy but an aspect of characterization - such as the comic self that is presented as such (as in the example of Danda but not the instance of Unoka). The second term also requires qualification because magnitude is not undifferentiated, and it is problematic to ascribe the absence of magnitude to comedy - all comedy. There is a comic magnitude in The Poor Christ of Bomba, for instance, that contrasts the comic simplicitas of Danda. The historical significance of the hegemonic contest in Beti's novel is far-reaching in presentation whereas Danda's escapades never achieve such elevation. Even in tragedy, there are different levels of magnitude. As grave as it is, especially when linked to the communal tragedy suggested by the brutal erasure or corruption of a civilization, Okonkwo's personal tragedy does not have the same sort of cosmic inevitability as Oedipus's fate. One points to a communal tragedy, the other signposts a universal blindness. In between the different dimensions of magnitude are the in-between states that account for the existence of such terms as "tragicomedy" and "comic tragedy." While this sort of particularization does not necessarily invalidate Aristotle's argument, it emphasizes the specific attributes that are essential in the characterization of comedy. It also provides analytical pointers with which to examine Agnes Heller's description of the comic novel as "an encyclopedia of all comic phenomena" (Heller 76). 
In Nwankwo's novel, Danda's character or comic self is established quite early and becomes the pivot on which the novel turns. Danda does not have the hubris or the self-doubt of the classic tragic character. Instead, his self-positioning is as a daring man of the people whose aim is to de-construct in his own fashion - even if momentarily - the social codes (both local and foreign) that impede his lustful appreciation of life. His nickname, "Rain," is telling. Danda is the colorful and 'natural' event that irrigates the hearts of the people, particularly the lower class. The result is not a plenitude of crops but a surfeit of laughter and a re-appreciation of certain ways of being. Danda's aim can be said to be a new semiosis or meaning-making process without hard boundaries. This aim is helped by what Emmanuel Obiechina discusses in Culture, Tradition and Society in the West African Novel as the fraying of traditional institutions: "As soon as traditional society loses its collective outlook and the social forces which held it together, social non-conformism and rebels begin to appear. Thus Aniocha produces Danda, who, for all his poetic imagination and apparent light-hearted attitude, is at heart a rebel (242). If Danda can be described as a rebel, then he is a rebel by being - not ideology. Danda's main purpose is to enjoy life as he sees it, not to fundamentally or dialectically engage with the larger issues in his society. But his enjoyment of life sometimes clashes with certain social codes, thus causing what may qualify as a self-centered rebellion. As Danda asks, after hearing about how Jesus Christ suffered for the world: "Why suffer for the world?" (52). Danda claims to speak or act on behalf of no one else but himself. He is like a mobile comic whose actions are capable of inspiring social protest, but who does not principally or even consciously direct his actions towards that goal, which may explain why they never achieve any such social significance.

When we first see Danda, he is the only one who is not content enough to only admire the "land-boat" of his kinsman. Instead, he gets into the car, somewhat vicariously actualizing the fantasy of the admiring onlookers, and dares anyone to evict him. When the owner threatens to do so, Danda challenges him: "You are not fit to" (8). Not surprisingly, the crowd supports Danda. Nwankwo suggests Danda's understanding of crowd psychology and situational dramatics. It is not incidental that Danda's entrance is usually marked by a characteristic greeting, "Kliklikli" (9), which sounds like a performer's entry signature. Danda's sense of himself as a performer and his unrestrained lust for life are signal aspects of his characterization. When he arrives in Ndulue's home, Danda does not wait in the shed like others because he is "one [who] had never recognized the demarcation" (9) between the lower and the upper class. Once inside Ndulue's home, Danda attempts to inspirit the gathering with his joie de vivre or rain mystique, but this particular audience does not properly appreciate him:

'Oi! Oi! Oi!' cried Danda, moved to ecstasy by his own fluting. Then he drew an impudent finale and waited for the type of applause he was used to. There was none. Danda burst. 
'Why are we so solemn? Why are we dressed up? Have we forgotten how to stand on our heads?' Danda stood on his head. And waved his legs in the air' (13).

As Danda tells his friend, Nnoli Nwego, later: "I have eaten the world" (14) an interesting encapsulation of his vision of himself and his goal. In Nwankwo's novel, this recurrent motif or aspiration to "eat" the world, with all the joyous (not cannibalistic) abandon that this purposely culinary verb is capable of evoking, is often realized through moments of comic performance such as Danda's trip to Ndulue's house. Danda's itinerancy, his bridging as well as exploitation of (class) contrast, and his robust lust for life (not the tragic hero's pursuit of glory) are important characterization factors.

Danda's character, especially his performative mobility, evokes the trickster motif in the African oral tale. While the epic heroes in African folklore mainly have their correspondences in the tragic figures (such as Okonkwo) in the modern African novel, the trickster figures (such as the tortoise and the spider) mostly have their human incarnations in the African comic novel - in characters such as Danda. Danda's mobility is evident not only in his constant physical movements but also in his ability to adopt whatever persona seems to suit his purpose. When he joins the church, for instance, and even stays long enough to be baptized, he appears to modulate his behavior - even though he never entirely understands the significance of his new commitment. His new membership does not, however, stop him from fraternizing with 'non-believers'. In doing so, he blurs the lines of religious division, almost in the same manner as he troubles social hierarchies and lines of demarcation. When the catechist asks him why he is "drinking with spirit-worshippers," his old self reasserts itself: "What is wrong with that?" (63). Danda's performance as a Christian has obviously not erased his old self. But that performative mobility has also created questions, even for Danda himself, about his true self-definition. As Danda muses: "Some people say that Danda is a tortoise, others that he is mad. I am not mad, people of our land, but I am not sure that I am sane" (63). This uncertainty (a single plurality or a dual singularity) - attributable in this context to Danda's agwu, the deity that bestows creativity as well as madness - explains Danda's existence in the interstices of the communal imagination. He is not considered mad enough to be restrained, but he is also not seen as sane enough to be dealt with with the full force of the traditional judicial system. So, Danda exists as a boundary figure with uncommon privileges - mainly his "prerogative as the Aniocha village Akalogholi (nonconformist and good-for-nothing)" (Obiechina, Culture, Tradition, and Society 84). This sort of location/non-location is relatable to Robert Pelton's discussion of the "ambiguity" of the trickster (27): the "multiformity [that] accounts for both ... [his] comic value and his mythic importance. He is both a schemer and a thief, a lecher and an ingrate, yet he is, proto-typically, 'wonderful'" (28). C.W. Spinks also attributes to the ambivalence of the trickster "the energies which allow him to serve human cultural purposes" and "the source of his complexity, for out of it arises an immense amount of laughter and social satire" (180-181). 
Mongo Beti's The Poor Christ of Bomba is another example of comic density in the modern African novel. As in Danda, characterization - the comic self - is of primary importance in Beti's novel. The titles of the two novels actually underscore this importance. While Nwankwo's novel is clearly eponymous, Beti's novel can be said to be descriptively so since the "poor Christ of Bomba" is a descriptive reference to Father Drumont - the missionary to whom "Christ and himself were all one" (3). Beti's novel is more ideologically oriented than Nwankwo's. Emmanuel Ngara reckons The Poor Christ of Bomba (along with Achebe's Things Fall Apart and Ngugi's Weep Not, Child) among those African novels that point to the "expression in artistic form of the rising political consciousness of the African people" in the period between 1957-1967 (30). Obiechina classifies it as one of the Francophone African novels that were concerned with "La Situation Coloniale" - specifically, "misguided missionaries are shown foolishly uprooting traditional institutions without any hope of replacing them with something comprehensible and meaningful" (Language and Theme 82). For all its ideological seriousness, The Poor Christ of Bomba is another classic African comic novel, amply evidencing what Irele describes as Beti's "characteristic satiric tone and manner" (The African Experience 154). This tone (and manner) is imaginatively actualized through the sort of systemic contrast (and irony) that is fundamental to the structure of Beti's novel. While the contrast in Danda is mostly internal (between Danda and the rest of the society, particularly the sanctimonious elders), the contrast in The Poor Christ of Bomba is mostly between Father Drumont/French colonialism and the villagers/Africa. Because Father Drumont does not understand the African society in which he lives, and because he ascribes inferiority to a people and culture that he does not comprehend, his actions tend to be not only ironic and comic but also ultimately futile. Beti's "poor Christ of Bomba" illustrates Heller's observation that the main character (or one of the main characters) in a comic novel often "dwells not in a pragmatic world, but in a dream, an illusion, in his own phantasm or phantasmagoria" (78).

When we first see Father Drumont, he shows himself capable of the sort of performative mobility already noted in Danda's case. In this case, he presents himself not simply as a good Christian but as Christ (or the equivalent). Performativity in this instance almost borders on impersonation and is capable of creating confusion instead of erasing demarcations. Later in the novel, someone remarkably tells the Father: "Father, it seems to me that if Jesus Christ had really thought of us, he would have come himself to discuss the matter with us. Then perhaps he would have consented to let us dance" (56). But at the beginning, it is not even the claim of ontological or structural equivalency - Father Drumont as Jesus Christ, Jesus Christ as Father Drumont - that causes laughter among the villagers. It is the Father's death-like (or Christ-on-the-cross) manner. Unlike Danda, Father Drumont does not appear to understand crowd psychology, so people laugh at - instead of with - him. Interestingly, when Sango Boto (a medicine man and one of the Father's arch opponents) speaks to the people, 
they listen to him "in complete silence, without a murmur of disapproval, even a cough. The same people who always coughed throughout the Mass now listened as if to the Messiah himself" (76). Father Drumont's character is also highlighted by the contrast that the narrator makes between the Father Superior (Drumont) and the Vicar. While the Vicar had only been in the village for a year, "he speaks our language better than the Father Superior, who speaks it so strangely that people say they only understand him next day, after thinking all night about what he said the day before" (8). Father Drumont's strangeness is his unintended comic attribute. So too is his poor comprehension of human nature. For instance, his trust in Zacharia, his cook, is one of the major ironies in the novel. As the narrator ponders: "Only when the bishop comes to the mission will you find Zacharia in the kitchen. The Father knows all this perfectly well, but he refuses to believe that Zacharia is really bad" (10). Meanwhile, Zacharia encourages a comic perception of Father Drumont.

Father Drumont's itinerancy as a missionary is also a characterization tool that Beti uses to point up his comic sides. Apparently, the Father had not visited the Tala country for three years as punishment for "their bad conduct, from their refusal to recognize him who came down to earth for them, and died on the cross to save them from sin" (5). In the Father's imagination, the "punishment has certainly been hard, but it was necessary" (5). The tone, and its underlying assumption, supposes the people's longing for the Father's benevolent presence. But this sort of semiosis signifies the missionary's contextual overvaluation of himself and Christian theology. When Father Drumont undertakes the journey to Tala, it is quite ironic how the people had fared without his presence. Many of the converts had taken two or three wives and actively resumed their relationship with medicine men. The self-punishing Father blames himself, as the narrator recounts: "Oh, the strategem has failed too dismally. How could it be otherwise in this Tala country, this kingdom of Satan, this Sodom and Gomorrah?" (12). But this stage of the tour is only the beginning of Beti's revelation of the Father's near epical ignorance and failure. When the sixa (the Catholic 'hostel' for engaged women) that had functioned under the assumed vigilance of the Father is later revealed to have degenerated into a brothel, more or less, the consequent uproar leads to the virtual collapse of the Catholic mission and the departure of Father Drumont. The narrator, who is enamored of Father Drumont and French civilization, reflects in a tone that oscillates between lament and realism: "The Father has gone and will never return. What would he come back here for, anyway? We loved him so little...As if he were not one of us...for he was not one of us..." (216)

In reality, Zacharia the cook had more managerial control over the sixa than Father Drumont. The plot of The Poor Christ of Bomba is in fact founded on a functional contradiction or tension between Father Drumont and Zacharia. One assumes what he is not. The other lives, as well as masks, what he is. The result is probably as near tragic as comedy can be without ceasing to be comic. Read 
together as a contrastive characterization principle, these two main characters embody the plot of the novel. In a similar manner as Danda progresses according to Danda's eccentric rhythm, The Poor Christ of Bomba unravels according to the rhythm of dis/harmony between Father Drumont and Zacharia. The Father does not quite belong in the same category as Ndulue and the elders in Danda because he is a cultural outsider,_but Zacharia is as much a trickster figure as Danda. Their association with eating (Danda) and cooking (Zacharia) is interesting in the way it signifies their folkloric desire for the basic and the everyday, not the hegemonic or the impossible. While Zacharia does not have Danda's 'privilege', he can sometimes rise above his baser self - apparently. He is more often to be heard making jest of Father Drumont, but he also tells the Catechist at one point: "I'm always telling the Father to take care, but he's always too trustful" (97). In an essay in which he examines the influence of folklore techniques on the form of the African novel, S. Amanor Dseagu argues: "Most African novels, if not all, use character, not as a reflection of individualism, but as a reflection of the ideals of communalism, group solidarity, and conformity to emphasize the principles of Africa's morality" (596). But the character of Zacharia is more functional than representative and, as in the folktale, didactic by negation. Zacharia is the selfcentered insider who contravenes every sense of morality by transforming the sixa into a brothel. The result is the ruin of the system. Zacharia is a lesson not because of what he represents but because of what he fails to represent. He fits into William Doty's interpretation of the didactic nature and function of the trickster tale: "Trickster stories [...] motivate (often by negative example) change, development, growth, and careful regard for behavioral mores of the community that enjoys them" (11).

The comic tension in The Poor Christ of Bomba is between what Father Drumont is and what Zacharia is not, what Father Drumont believes and what Zacharia knows. When, during the disappointing Tala tour, Father Drumont wonders why the people ever came to Mass in the first place if they could not remain steadfast Christians. Zacharia responds:

"The first of us who ran to religion, your religion, came to it as a sort of... revelation. Yes, that's it, a revelation; a school where they could learn your secret, the secret of your power, of your aeroplanes and railways...in a word, the secret of your mystery. Instead of that, you began talking to them of God, of the soul, of eternal life, and so forth. Do you really suppose they didn't know these things already, long before you came?" (30)

This disconnect, on which the novel's systemic contrast is founded, in part explains the mocking response of the villagers to Father Drumont and his selfcharacterization as Christ. Contrastive as well as collective characterization is as important in Beti's novel as it is in Nwankwo's Danda. In The Poor Christ of Bomba, Beti is particularly ironic in the manner he presents the characters individually and collectively. The pompous Father Drumont turns out to be a 
functional ignoramus whereas the 'primitive' Africans reveal themselves capable of a functional understanding of colonial economics and imperial logic. In Danda, Nwankwo's methods of characterization include semi-cartoonization. As Obiechina has also observed:

In Danda, there is a gallery of characters touched with a dab of Nwankwo's comic brush. Danda, the hero of the tale, is described as a lithe, thin man draped in a blue cloak lined with small bronze bells which tinkle wherever he goes. His father, Araba, is a short, stocky man of title, with restless eyes and disproportionately large head [...] Okoli Mbe (like the tortoise from which he takes his name) is short with narrow head and sharp cunning eyes (Culture, Tradition and Society 87).

These physical features are exterior pointers to interior attributes or behavioral characteristics. This sort of characterization principle adds to the comic texture of the novel regardless of the seriousness that the villagers attach to existential issues and questions.

Besides characterization and the related issue of systemic contrast (and irony), point of view is another important aspect of the poetics of laughter in the African comic novel. The choice of the young Denis, with his experiential and ideological innocence, as the narrator in The Poor Christ of Bomba is an important one with respect to point of view in the novel. Denis describes Zacharia as a bad person several times, but he is not always able to correctly decipher what Zacharia is up to. For instance, Denis reports to the knowing reader Zacharia's sexual encounters without himself realizing the import of his account: "Zacharia must be ill again. His door hasn't stopped creaking since we went to bed. What is all this coming-and-going? Funny. I thought he'd got over his diarrhoea" (43); "Hullo! There goes Zacharia's bed again" (57). Eventually, Denis himself falls in love with Catherine, one of Zacharia's women. Unlike Zacharia, Denis is enthralled by his ungrounded vision of France and French culture, including its perceived flag bearers such as Father Drumont. When the sixa scandal becomes public knowledge, Denis muses: "I'm certain nothing like this ever happens in the Father's own country" (188). This comparative privileging of France is another indicator of how much Denis's relationship with Father Drumont has shaped or reshaped his view of the world. Denis's innocence (or ignorance) and othercultural immersion - including his super-elevation of Father Drumont as an embodied signifier - make him a rather unreliable narrator whose interpretations and sympathies often add to the comic texture of the novel.

In Danda, the point of view is not fundamentally serious, even when the narrative ventures into or references the realm of myth. During Araba's near-fatal illness, the narrative incorporates the Igbo myth about the land of the dead being seven lands and seven seas away from the land of the living:

The road to spirit-land passes seven lands, seven seas, seven plains, seven deserts. The stopping places include where the sun was born and where it was bathed with blood, the home of the maimed who had lost their lives by violence, and finally 
led to the home of the old woman who gave the travelers spirit food which sets the mark of no return on their foreheads. Araba reached the old spirit's hut but there stopped his ears, bound his head with akwala string and refused to eat the food. He would not cross the line that divided spirits from men for if he did that Nwokeke would triumph (118-119).

This narrative however de-emphasizes the seriousness of the myth by refiguring its essence. Nwankwo's extension of the traditional image of seven lands and seven seas, which is a symbolic pictorialization of the known world through panoramic lenses, into seven plains and deserts (as distinct from seven lands) creates a new geography with questionable significance in this context. This extension apparently lengthens the journey without deepening its meaning. In fact, this atomization seems to call attention more to the passage than the essence of the transition. Araba's refusal dramatics, the reimagining of a metaphor as literal reality, sharpens the comic (or at least the non-serious) touch to Nwankwo's re-presentation of the myth. The myth of transition is thus transformed into a hyperbole about recovery from sickness. As Karen Armstrong reminds us: "Like poetry and music, mythology should awaken us to rapture, even in the face of death and annihilation" (8). In his own study, Alexander Eliot defines myth as "the glistening interface between consciousness and creative chaos" (282). Nwankwo's re-presentation qualifies as myth in the sense of myth as "that quality of fancy which informs the creative or configurative powers of the human mind in varying degrees of intensity" (Okpewho 69), but it neither enraptures nor glistens in a transformatively conjunctive manner.

Other instances of recontextualization that affect the literary character of Danda include Nwankwo's direct translations from the Igbo language into English - particularly his translation of "car" as "land-boat" (ugbo ani) and "kinsmen" as "sons of my father" (umunna). These are transliterations, either in form or in spirit, of words and concepts that have a neutral or non-comical existence in the traditional Igbo semiosphere. Within the English language context of Nwankwo's Danda, however, such a translation as "land-boat" does not retain the same neutral existence. When the natives refer to a car, which had previously been outside their sign system, as a "land-boat," they produce a new life of the sign for "boat" by a combination of the route of this new vehicle (land) and a known means of transportation (boat) into a contextually illogical translation: the boat that travels on land. This 'illogicality' encodes their bewilderment as well as captures their attempt to comprehend a new reality - a conjunction that is simultaneously new and old. "Land-boat" becomes not just a word but also an ironic cultural narrative. The contextual illogicality of this new signifier de-neutralizes it and somewhat orients it towards the comic. In The Poor Christ of Bomba, the situational illogicality of Father Drumont's mission, as Zacharia points out, and the missionary's 'thingification' of himself in the process are important aspects of the novel's comic thrust. As Henri Bergson argues in Laughter: An Essay on the Meaning of the Comic: "The comic is that side of a person which 
reveals his likeness to a thing, that aspect of human events which, through its peculiar inelasticity, conveys the impression of pure mechanism, of automatism, of movement without life" (87).

Movement is essential in both novels. But while Danda's movement is full of life, Father Drumont's seems rather lifeless or robotic. While both are comic characters, the attitude of the two novelists to the two characters is not the same. In Danda, Nwankwo evokes a world and culture that he identifies with and in which Danda is a comic insider. Nwankwo therefore uses constitutive irony and humor in which "the very work becomes ironic and humorous in just the way that the world it describes is supposed to be" (Heller 71). In The Poor Christ of Bomba, Father Drumont is a comic outsider, whereas Beti evidently situates himself as an insider, so Beti's use of irony and humor is essentially regulative. In regulative irony or humor, "the very distance between the ironist or humorist and the butt of his humor is made manifest" (Heller 71). Because Beti conditions the reader not to sympathize with Father Drumont, the novel's tragic potential is negated. Unlike tragedy, which thrives on the reader's emotional investment, the comic "appeals to the intelligence" and "is incompatible with emotion" (Bergson, 139). Even when Father Drumont describes himself as "a failure, a sacred failure" (150), he is unable to rouse the sort of emotional response that is crucial in tragedy. $\mathrm{He}$ is not a comic character in the same way as Danda, but his presence only furthers - but does not subvert - the range of comic characterization. Although Danda and The Poor Christ of Bomba instantiate comic density, Nwankwo and Beti map in different ways the poetics of laughter in the African comic novel.

Maik NWOSU
University of Denver

\section{Works Cited}

Achebe, Chinua. Things Fall Apart. 1958. New York: Anchor, 1994.

AмuтA, Chidi. The Theory of African Literature: Implications for Practical Criticism. London and New Jersey: Zed Books, 1989.

Aristotle. Poetics. Trans. S. H. Butcher. http://philosophy.eserver.org/aristotle/poetics.txt

Armstrong, Karen. A Short History of Myth. New York: Canongate, 2005.

Bakнtin, Mikhail. The Dialogic Imagination: Four Essays. Trans. Caryl Emerson and Michael Holquist. Austin and London:U of Texas P, 1981.

Bergson, Henri. Laughter: An Essay on the Meaning of the Comic. New York: Macmillan, 1917.

Beti, Mongo. The Poor Christ of Bomba. 1956. Trans. Gerald Moore. Long Grove, Illinois: Waveland Press, 2005. 
Dоту, William G.: "Native American Tricksters: Literary Figuras of Community Transformers." Trickster Lives: Culture and Myth in American Fiction. Ed. Jeanne Campbell Reesman. Athens and London: The U of Georgia P, 2001: 1-15.

Dseagu, S. Amanor. "The Influence of Folklore Techniques in the Form of the African Novel." New Literary History 23 (1992): 583-605.

Forster, E.M. Aspects of the Novel. San Diego: Harcourt-Harvest, 1955.

Heller, Agnes. The Immortal Comedy: The Comic Phenomenon in Art, Literature, and Life. Lanham, MD: Lexington Books, 2005.

Irele, Abiola. The African Experience in Literature and Ideology. London: Heinemann, 1981.

Ngara, Emmanuel. Art and Ideology in the African Novel: A Study of the Influence of Marxism on African Writing. London: Heinemann, 1985.

Nwankwo, Nkem. Danda. 1964. London: Fontana, 1980.

Obiechina, Emmanuel. Culture, Tradition and Society in the West African Novel. African Studies Series. Cambridge: Cambridge UP, 1975.

-. Language and Theme: Essays on African Literature. Washington, D.C.: Howard UP, 1990.

Oкреwно, Isidore. Myth in Africa: A Study of its Aesthetic and Cultural Relevance. London: Cambridge UP, 1983.

Pelton, Robert D. The Trickster in West Africa: A Study of Mythic Irony and Sacred Delight. Berkeley and London: U of California P, 1980.

Sophocles. Oedipus Rex. Trans. E. H. Plumptre. http://0-www.netlibrary.com.bianca.penlib.du.edu/Reader/

Spinks, C.W., Jr. Semiosis, Marginal Signs and Trickster: A Dagger of the Mind. London: Macmillan, 1991. 